\title{
Actual Issues of Planning of Well-Balanced Development of Innovative \& Investment Activities
}

\author{
Nadezhda A. Serebryakova ${ }^{1}$, Yuriy A. Salikov ${ }^{1}$, Olga Y. Kolomytseva ${ }^{1}$, Tatyana A. Pakhomova ${ }^{1} \&$ Natalya V. \\ Grishchenko ${ }^{2}$ \\ ${ }^{1}$ Voronezh State University of Engineer Technologies, Voronezh, Russia \\ ${ }^{2}$ Voronezh Institute of Cooperation (department) of Belgorod University of Cooperation, Economic, and Law, \\ Voronezh, Russia \\ Correspondence: Nadezhda A. Serebryakova, Voronezh State University of Engineer Technologies, 19 \\ Revolution Av., Voronezh, 394044, Russia. Tel: 7-910-749-7142. E-mail: nad.serebryakova@mail.ru
}

Received: May 21, 2015 Accepted: June 18, 2015 Online Published: July 15, 2015

doi:10.5539/ass.v11n20p193 URL: http://dx.doi.org/10.5539/ass.v11n20p193

\begin{abstract}
The modern factors of development of the country's economy require interdetermination and interdependence of the study of issues of planning of balance of innovative and investment activities, which has a very important meaning for economic systems and determines the scientific interest in this topic. The purpose of this article is the study of theoretical and methodological aspects of planning of well-balanced development of innovative and investment activities and development of practical recommendations, aimed at the increase of efficiency of economic systems. In order to achieve this purpose, the authors used economic and statistical methods of research and methods of economic \& comparative analysis. Methodological and practical development was based on the following approaches: process, program-oriented, complex and structural \& logical, and methods of comparison and modeling. The authors distinguish the determinants of planning of well-balanced development of innovative and investment activities of economic systems, which, unlike the existing approaches, allowed forming the system of targeted landmarks and limitations which guaranteed the optimal conditions for effective functioning and development of economy of macro-, meso- and micro-levels; the authors offer a program-oriented approach to the well-balanced development of innovative and investment activities of economic systems, the novelty of which consists in the fact that it is used as a modern technology of planning which facilitates solving tasks of limited and creative type, which, in its turn, creates possibilities for creation and support for balance between the volume of investments and development of investment activity. Besides, these recommendations as to formation of balance of investments for the purpose of increase of efficiency of innovative activity contain methods and means for solving problems of well-balanced development and allow implementing analytical, synthetic, and practical interests of all economic subjects in the process of systemic adaptation to the changes of external conditions. The recommendations, formulated in the research, may be used in the work of federal and regional authorities; in the process of improvement of innovative and investment activities of economic subjects of micro-level.
\end{abstract}

Keywords: management, balance, innovations, investments, planning

\section{Introduction}

Innovations and investments, by virtue of their nature, are oriented at long perspective, which cannot be viewed in isolation from planning their well-balanced development. Economic systems of macro-, meso-, and micro-levels have to be able to develop and implement the effective innovational policy which is founded on the process of planning of well-balanced development of innovative and investment activities. The necessity of provision of balance is pointed out in orders of the range of federal and regional governing documents and programs which stimulate the development of economy. The balance of innovational and investment spheres of the economy is an essential condition for intensification of production, increase of its efficiency, provision of high growth rates, and solution of many other important socio-economic problems.

The factors which caused the aggravation of the problem of the economy's balance include the accumulated disproportions of intersectorial and intraindustry nature, which emerged dude to specifics of the process of reproduction at the previous stages (policy of maximization of growth rates of leading productions by means of 
sectors of economy which were considered to be less important; emphasis on extensive sources of economic growth; insufficiently effective use of external economic ties and, in particular, of loaned resources, which leads to tension of balances of payment, etc.).

At present, there is a growing importance of using the methods of preservation of balance under conditions of quickly changing proportions. The need for intensive change of the structure of economy strengthens the possibility of temporary disproportions and, consequently, the necessity for accurate account of the society's resources and their operative management, and for improving the mechanism of their distribution. This refers to all important factors of reproduction: work force, capital investment, and natural, material, and consumer resources (Boudeville, 1966).

Solution of the actual problem of the country's economy's transition to innovational path of development is not possible without planning of well-balanced development of innovative and investment activities. Despite the significance and importance of the task before the country, this problem is not thoroughly studied in economic literature and various scientific research: there are no theoretical provisions for planning the well-balanced development of investment and innovational activity of economic systems; factors and tools of the balance of innovative and investment activities are not determined; the system of indicators of evaluation of balance is not developed. All of this predetermines the actuality of the study of issues of development of innovative and investment activities of economic systems.

The planning tools help to determine and provide the task-oriented development of any economic system. At present, under market conditions, there is no unified planning at the scale of the country; new property forms appeared, and new economic connections between manufacturers and consumers emerged, which are regulated by the Civil Code of the Russian Federation.

The planning methods are the foundation for joint management of all economic systems. After the first stage, there goes the second one and all the others, which relate to the production or realization of goods and services. In authors' opinion, it is impossible to connect or cooperate all the stages of production process without using the methods of planning.

Humans faced the need of planning their actions very long ago, back in ancient times. Any understanding of an action requires setting of the goal. Then it is necessary to choose means and methods of achievement of the set goal. Eventually, planning was widely acknowledged.

In the $19^{\text {th }}$ century, European and American scientists began developing and generalizing planning. The founders of the planning methods in economic are: Frederick Winslow Taylor (1991), who wrote, "There will be no rich and poor countries - they will be educated and ignorant ones", thus implying that the source of knowledge is planning, as a management function; Henry Ford (1924), who opened wide possibilities for use of planning, its experience, and, in particular, the principles of organization of mass production of consumer goods, in methodological aspect; Henry Laurence Gantt (1917), who started to work with F. Taylor and the diagram that he offered is still actual for management and provides a graphic illustration of the plan of works; Henri Fayol (1923), who defined planning as the most important administrative function, limited by boundaries of specific economic system of micro-level.

Planning at the level of state was first used in Russia in 1917, after the October Revolution. All enterprises became the property of the society, which led to many questions as to the state's managing them. This situation supposed determining forms, methods, and tools for economic management of meso- and macro-level of economy. As a result, the work of state authorities was organized, which developed the plans of the country's economy (Busarina, Morkovina, Budkova, \& Kolesnichenko, 2014).

In the USSR, the use of concentrated planning showed the perspective of strategic management and planning at the level of the country, which allowed preventing unemployment and crises. The practice of planning in the USSR in 1930s was used by the economist John Keynes (1978), who substantiated the significance of state regulation of the economy. After that, programing began to be widely used within planning in many countries of the West in the practice of economy.

Principles of planning of macro-, meso-, and micro-levels of economy were founded and tested in the USSR; in spite of that, all modern methods of planning, like "Just in time" (Precisely in time for workers, 2008), MRP (Planning of needs for materials, 1999), ERP (Kaniran, 2005), and others, were created and used abroad.

The sense of the process of planning consists in specific goals and tasks of development of all economic system in the specific period of time. The meaning of planning opens in the possibility to use all factors (external and internal) which guarantee the favorable conditions for effective functioning and development of economic 
system. Planning supposes formation of aggregate measures which determine the algorithm of achievement of set goals in view of possibilities of the most effective use of resources by economic system. Necessity for planning under modern conditions of economy results from huge size of production and realization and from requirements of scientific and technical progress, i.e., it must fully take into account and use innovations in science and technology (Chebotaryov, 2007).

The balance of the development of innovative and investment activities of economic systems supposes harmonization of all components of these processes, in particular: legal base for innovative and investment activities; innovative and investment policy of macro-, meso-, and micro-levels; investment and innovative potential of economic systems; measures which facilitate the increase of innovative and investment activity of economic systems, etc.

Formation of effective cooperation of investors and economic systems is one of the most important vectors of development for usage of investment resources in innovative activities. Creation of the mechanism of planning of balance of innovative and investment activities supposes the use of approach which will allow ensuring harmony of goals and structuring of indicators.

Balance of innovative and investment economic systems supposes the determination of the most effective paths of realization of investment into innovative activities in two projections. Firstly, determining the objects of innovative activities and, secondly, forming the sufficient volume of investment resources, in view of priorities of achievements of scientific and technological level of economic systems which ensure the issue of innovational products, evaluation of need for innovative and investment projects, in quantitative and qualitative measurability of scientific \& technical, investment, and innovational potentials.

Implementation of planning of balance supposes the programs of development of investment and innovational processes and the most accurate evaluation of their implementation efficiency. Innovational development of the Russian Federations should be in balance with investment processes, which will allow combining efforts and resources of the state and entrepreneurial sector of the economy for their development.

\section{Methods and Materials}

Under limitation of investment resources, the most perspective way of recovery and provision of the balance is the increase of efficiency through use of innovations. That's why the issue of ties and relations between balance and effectiveness, as economic categories and specific economic parameters, is of special interest.

The main economic precondition for transition to innovative path of development and quickening of scientific and technical progress is the change of existing proportions which allows deleting tension in economics, caused by disproportion between the scales of simultaneously implemented goals and programs, on the one hand, and existing resources and level of rationality of their use, on the other hand - as well as by disproportions in the structure of the resources. At that, analyzing the reasons for existing problems of imbalance of innovative and investment spheres, one should understand the most important thing: these problems are caused not so much by globality of the current tasks, as by insufficiently effective use of possible innovations and investments (Sibirskaya, Gryshchenko, \& Syroizhko,2014).

Thus, on the one hand, the balance may be reached by the full and effective use of innovative and investment spheres of economic systems, and, on the other hand, balance depends on the right qualitative and quantitative ratio of not only innovational and investment activities of the economic systems.

An important role in strengthening of balance belongs to other links of economic mechanism. It is necessary to fully refuse from orientation at gross indicators, which do not characterize the final economic results and inevitable lead to violations of balance, creating the increased demand for various resources. They should be replaced by indicators which reflect the level of satisfaction of needs and efficiency of resources use. The consistent orientation of planning and economic levers at interests of consumers is an important and necessary link in provision of balance of the economy in whole. Besides, it is advisable to form a system of planned reserves at various levels of economy, as a means for protection from unpredicted changes (Lundvall, 1992).

Balance of innovative and investment spheres should be comprehensive and exclude the balance in certain areas by means of its violation in the others. However, this requirement is difficult to realize due to limited resources. As a result, constant maneuvering of resources becomes one of the main functions of planning. Depending on economic, social, or political situation, and on current purposes of development, on ideas of optimal state of economic system, which are characteristic of one or the other stage of economic growth, the priorities change, and current resources are taken from certain spheres and sectors of economy into the others. 
Under condition of limitation of resources, their shifting for the purpose of provision of balance in one area by means of temporary or full loss of the balance in another area cannot be considered an anomaly or referred to wrong economic methods of management. It seems that necessity for maneuvers will always exist.

However, the re-orientation of resource flows should be performed, taking into account its consequences for the economy in whole and its areas which are currently considered to be less important. At the same time, the deliberate change of proportions in the economy should not be accompanied by shifts which mean the violation of balance at various areas of economy, as a result of weak control of the society of economic processes. This requires searching and using indicators which fix the moment, level, and factors of balance violation, disparity of actual and planned proportions, etc.

The phenomena of imbalance of development of innovative and investment spheres do not result from their sense, they do not reside in it, but are the result of subjective reasons, or the result of specific objective factors of the current moment, or as a consequence of conditions of the global economic scale.

Supporting the balance is complicated by some objectively caused unfavorable tendencies in the dynamics of efficiency of the resources use, caused, in particular, by lack of potential economic effect of improvement of traditional types of technology.

However, as the experience shows, the main reasons for violation of balance are subjective ones. This is a deviation from requirements of scientifically substantiated planning, consisting in implementation of concepts of development of economy which supposed long preservation of previously reasoned top-priority position of some spheres and areas of production at the expense of others, or the ones that were initially based on insufficiently substantiated ideas on necessary priorities; in underestimation of economic and social significance of complex satisfaction of requirements of society and corresponding development of the spheres of economy; in unrealistic planning of certain indicators, especially of the growth of production efficiency, and toleration of elements of clear imbalance of the plans (Serebryakova, Sibirskaya, Stroeva, Petruchina (2014).

The reasons for violation of the balance include also deviation from planned tasks in the course of their fulfillment (the most typical deviation is overspending resources at the fulfillment of the production issue plan) and insufficient efficiency of plan and economic bodies at elimination of outlined disproportions.

Elimination of imbalance of planned decisions is one of the most important directions of improvement of planning, prevention of subjectivism in all its forms, and closing the gap between economic goals and real possibilities of innovative and investment spheres.

Planning of balance is the process which facilitates the changes for the better. Regardless of the sphere, in which planning is conducted, it still is performed through development of complex measures for achievement of the set goal.

Study of various methods of planning of innovative and investment activities and generalization of information allowed determining the main methods of planning of the development balance (Table 1).

Right planning of the well-balanced development of innovative and investment activities will lead to reduction of time required for complex projects and optimal use of resources. Use of the methods for planning of the balance will allow optimizing the project, determining the least possible time of realization, and using the capital more rationally; solving such problems as efficiency, management, control, and minimization of certain investment risks.

Table 1. Methods of planning of the balance of the development of innovative and investment activities

\begin{tabular}{|c|c|}
\hline $\begin{array}{l}\text { Methods of planning of the balance of the } \\
\text { development of innovative activities }\end{array}$ & $\begin{array}{l}\text { Methods of planning of the balance of the development of investment } \\
\text { activities }\end{array}$ \\
\hline 1 & 2 \\
\hline $\begin{array}{l}\text { Methods of conservative planning of the } \\
\text { balance of the development of innovative } \\
\text { activities - facilitates the preservation of } \\
\text { the level of work indicators with the help of } \\
\text { integration of previous methods, i.e., helps } \\
\text { to obtain better, or equal, results in the } \\
\text { planned time period than in the previous }\end{array}$ & $\begin{array}{l}\text { Methods of structural planning of the balance of development of } \\
\text { investment activities are based on the division of the program into specific } \\
\text { operations. The following stage is evaluation of the length of operations } \\
\text { and building a model where any movement of constituent elements of the } \\
\text { model shows their activities. This model is a graphical illustration of } \\
\text { connections and relations between all operations of the program. With } \\
\text { structural planning, this model helps to conduct a detailed analysis of all }\end{array}$ \\
\hline
\end{tabular}


time period.

Methods of adaptive planning of well-balanced development of innovational activity - aimed at receiving better results through the use of previous experience of use of means and methods through their adaptation to changing conditions. operations and correct changes in the structure of the program before its realizations.

Scheduling method of planning the balance of development of investment activities supposes development of a schedule which determined the start and the end of each operation, as well as their cooperation with other operations of the program. This schedule helps to determine the most critical operations, which require the most attention after the end of the program. In view of non-critical operations, the schedule helps to determine the time reserves to be used in case of untimely fulfillment. If the results of the projects are satisfying, it should be finished - otherwise, the further analysis for its improvement is required.

Program-oriented method is used in unclear and problem situations and is oriented at harmonization of goals and tasks and all types of resources and allows optimizing and coordinating the activities with the help of various criteria of alternative means of Program-oriented method of planning the balance of development of investment activities allows using the model and schedule simultaneously for preparation of reports on results of fulfillment of the programs. If the result is not satisfying, there is a necessity for correction of the model and the schedule. solving the currents problems.

The practical use of these methods will allow determining the development of problem situations which have a long-term nature, reducing the time of realization of investment project, automatizing the process of determining the parameters of realization of investment project, possessing information about the state and stages of project's implementations, and calculating parameters of investment project in view of already performed works in the course of project's implementation.

\section{Results}

The dynamics of economic development of economic systems directly depends on the level of innovative and investment activity of economic systems. That why there is a need for information which allows not only analyzing the economic activities but facilitates the development of managerial decisions as to elimination of disparities between inflow of investments and innovative activities. This information can be obtained with the help of monitoring. Is can characterize the processes in innovational and investment spheres of economic systems and, using the analysis, determine the reasons that prevent their dynamic development. Its use allows determining directions as to activization of corresponding directions of activities in economic systems. The received data can be used for completing the information about the state of investment climate and efficiency of innovative activities. The monitoring data allows suggesting measures for activization of investment and innovative processes in economic systems for quickening of dynamics of economic and social development and determining the volume of necessary investment resources for the development of innovative activities (Sibirskaya, Stroeva, Khokhlova, \& Oveshnikova, 2014).

The main purpose of monitoring of innovative and investment processes is systematized preparation of the data, based on the existing and additionally prepared informational resources which will allow conducting the analysis of economic activities of the systems and evaluating the real contribution into the process of planning of the balance of innovative and investment spheres.

This purpose supposes a range of tasks, required for its achievement:

- Forming new approaches to receiving and analyzing information which characterizes the process of attraction of investments into economic systems of various types (macro-, meso-, and micro-) and implementing the projects which allow solving the problems of innovative activities;

- Preparing the analytical information which is able to answer the question "How much investment assets should be attracted into the economy of the system, for the innovative activities to earn profit?";

- Creating informational provision which will allow not only conducting the wide analysis of planning of balance of innovative and investment activities in the economic systems but also evaluating the real contribution into the dynamics of evaluation of efficiency of activities for creation of conditions for improving innovative and investment climate; 
- Offering instrumentarium of managerial activities which allows analyzing deeply the real situation and determining the mechanism of stimulation of these processes in activization of corresponding directions of activities.

Formation of effective cooperation of investors and economic systems is one of the most important vectors of development in the usage of investment resources in innovative activities. Creation of the mechanism of planning of the balance of innovative and investment activities supposes the use of the approach which will allow ensuring the harmonization of the goals and structuring of indicators.

Let us conduct the analysis of the existing state and determine the cause-and-effect relations between innovative $\&$ investment spheres of activities of macro-, meso-, and micro-levels.

Let us analyze the structure of investments into non-financial assets. The main part belongs to investments:

- into main capital - approx. $98.4-98.8 \%$;

- investments into objects of intellectual property $-0.4-0.5 \%$;

- investments in other non-financial assets $-0.4-0.5 \%$;

- expenses for R\&D - $0.3-0.4 \%$.

Investments into main capital as to the types of main funds are presented in the form of a diagram (Figure 1).

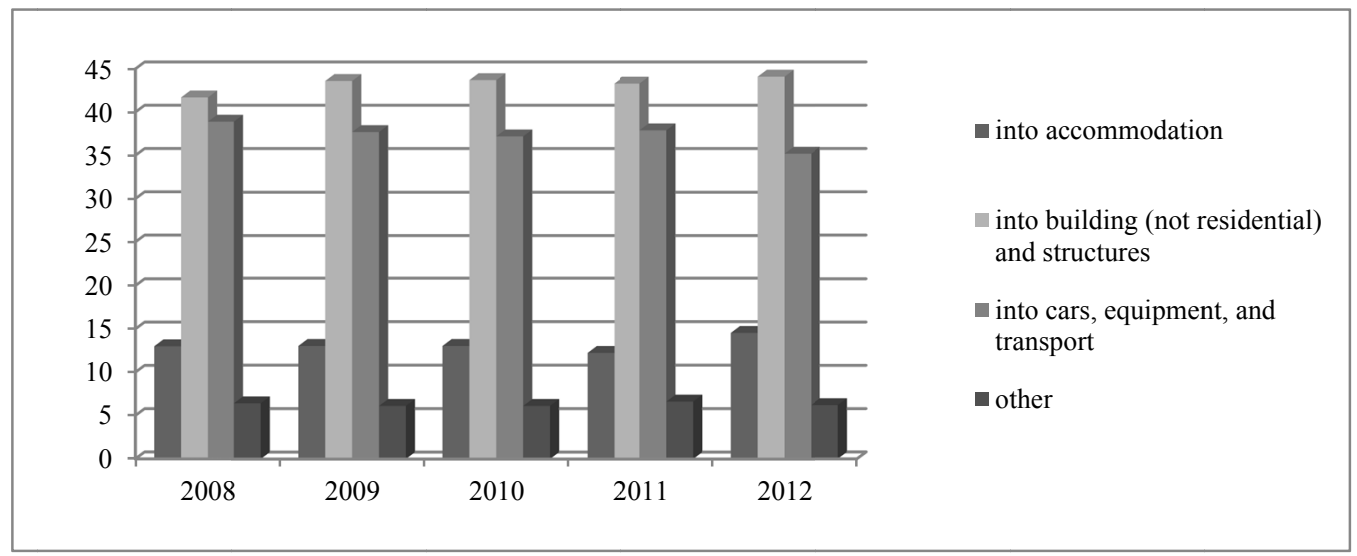

Figure 1. Investments into main capital as to the types of main funds

As is seen from the diagram, the structure of investments didn't change much over 5 years (2008-2012).

Let us present the investments into the main capital as to types and forms of property in the form of diagrams (Figure 2 and 3).

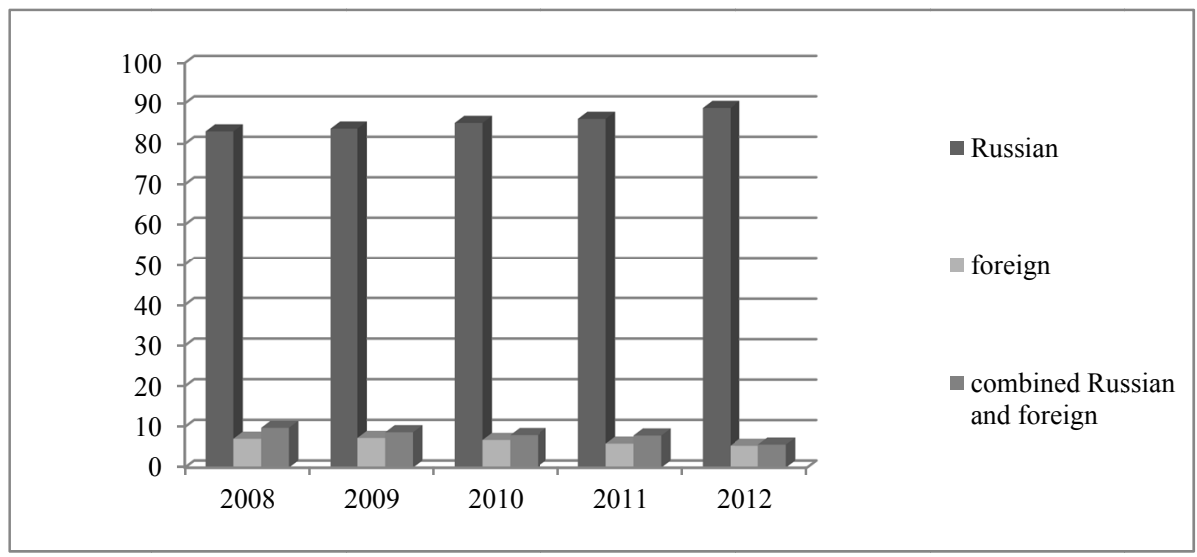

Figure 2. Investments into the main capital as to types of property 
This diagram shows that mainly Russian sources invest into the Russian economy and its main capital; the next diagram proves this.

Total investments into the main capital in 2008 in existing prices constituted RUB 6,716,222 million, which is $122.7 \%$ as compared to the previous year (in fixed prices); in 2009, the investments equaled RUB 8,781,616 million in existing prices, which is $109.9 \%$, as compared to the previous year (in fixed prices); in 2010 , the investments equaled RUB 7,976,013 million in existing prices, which is $84.3 \%$, as compared to the previous year (in fixed prices); in 2011, the investments equaled RUB 9,152,096 million in existing prices, which is $106.0 \%$, as compared to the previous year (in fixed prices); in 2012, the investments equaled RUB 10,776,839 million in existing prices, which is $108.3 \%$, as compared to the previous year (in fixed prices).

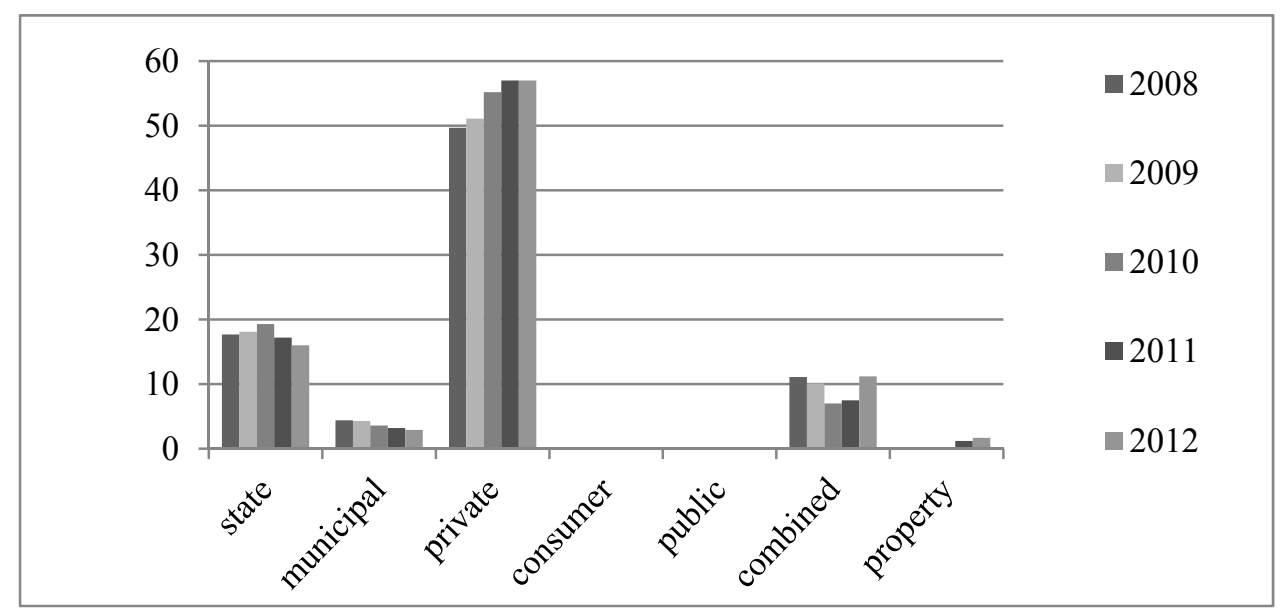

Figure 3. Investments into the main capital as to property types

As is seen from Fig. 3, the volume of state investments over the last five years didn't change much; the volume of investments into the main capital from municipal sources decreases, but there is a positive dynamics of private investments from $48 \%$ in 2008 to $57 \%$ in 2011 , with the latter volume preserving in 2012; the organization and enterprises of consumer cooperation invested practically nothing, as well as public and religious organizations; volume of investments from combined sources with the state share reduced a little over 2009-2011, but there was a positive dynamics in 2012; the newly emerged state corporations began actively investing into the main capital in 2011-2012.

Let is present the investments into the main capital according to the sources of financing in the form of a diagram (Fig. 4, 5, and 6). Figure 4 shows that the main capital is formed by means of attracted assets, and the next figure shows the sources of own and attracted funds over the period of 2008-2012.

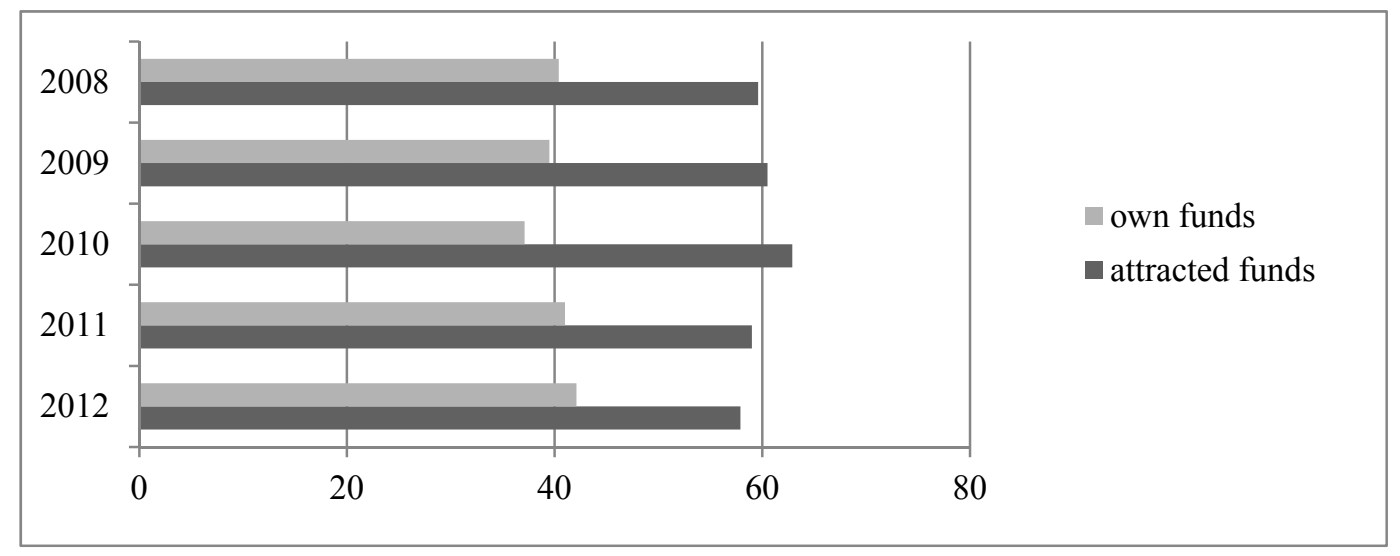

Figure 4. Investments into the main capital according to sources of financing 


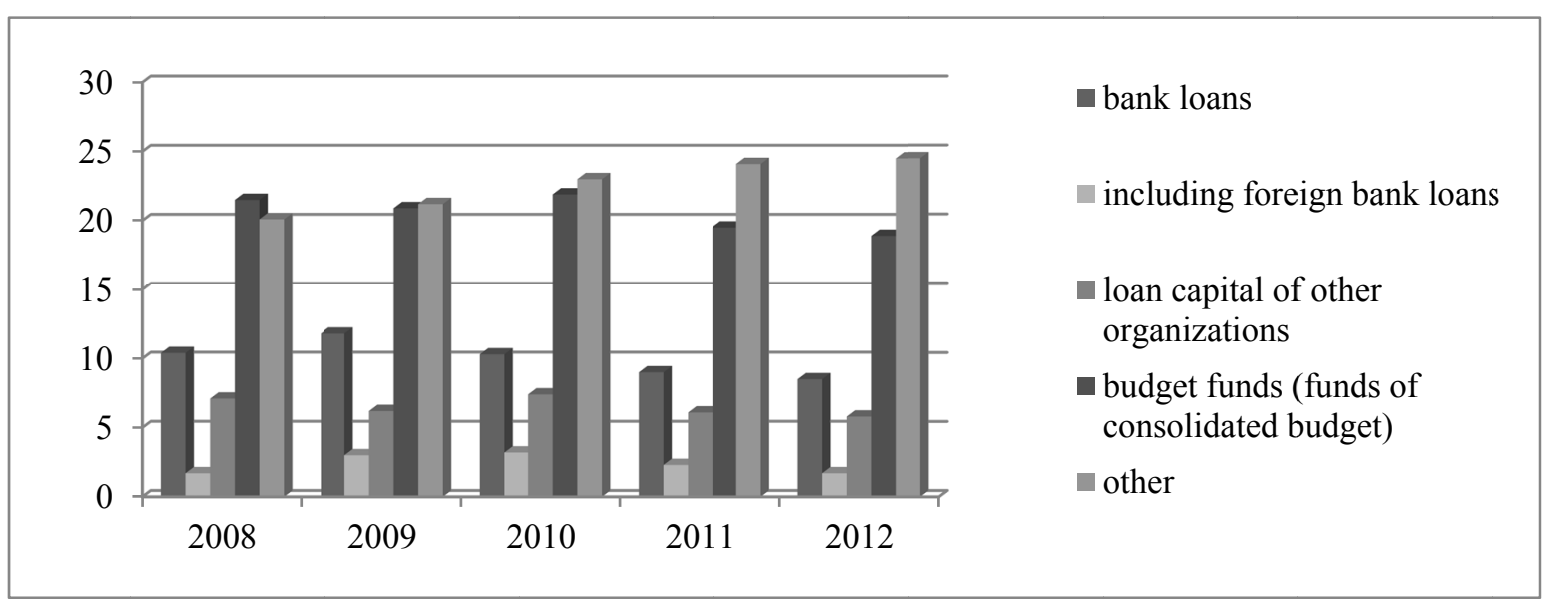

Figure 5. Investments into the main capital according to sources of financing by means of own funds

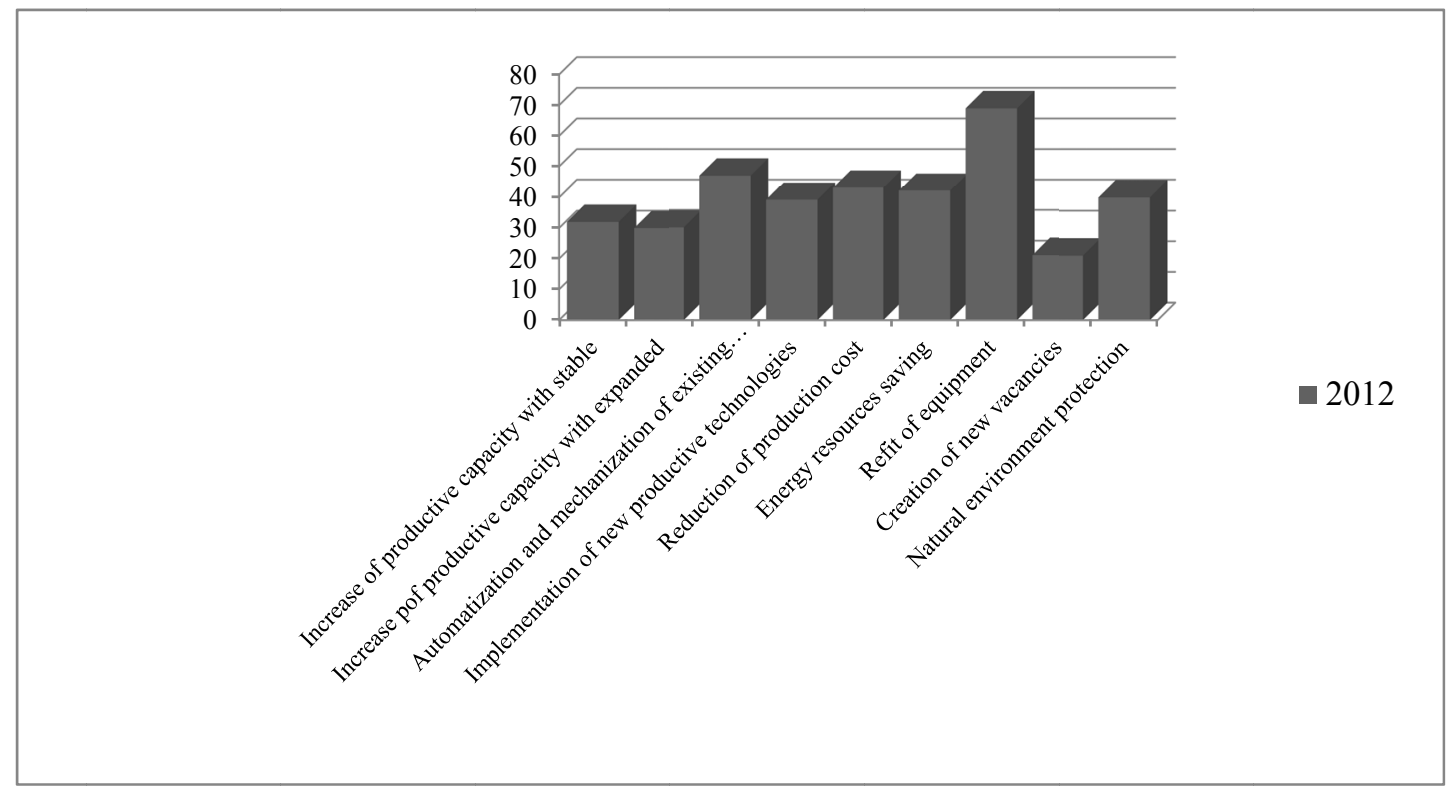

Figure 6. Investments into the main capital according to sources of financing by means of attracted funds

Distribution of organizations according to evaluations of purposes of investing into the main capital (based on the data of selective study of investment activities of organizations) in percentage of the total number of organizations - Figure 7 . 


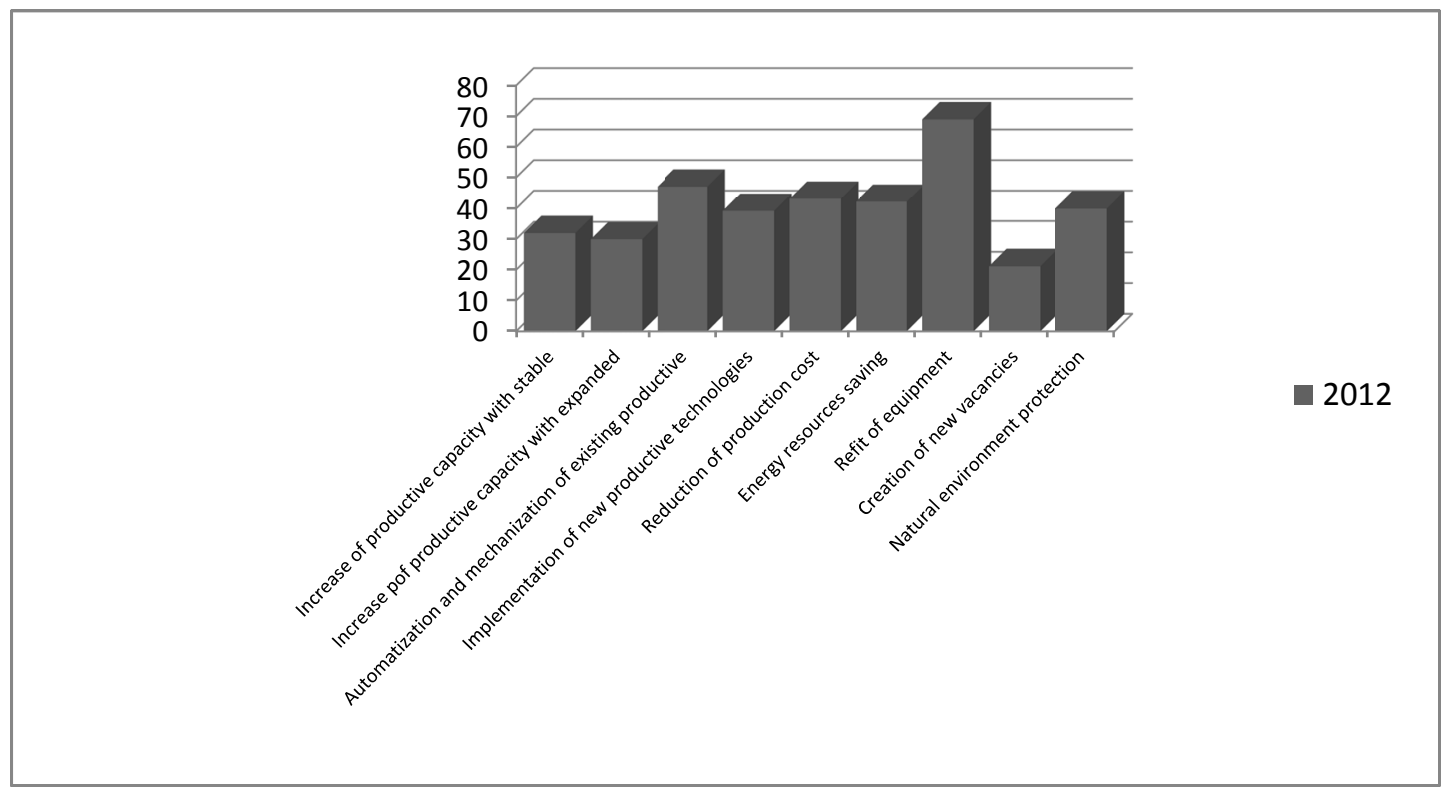

Figure 7. Distribution of organizations according to evaluations of purposes of investing into the main capital for 2012

Having analyzed the data, presented in the above figures, it is necessary no mark that the Russian companies do not have the purpose of investing into innovative developments.

Internal expenses for research and development in whole in the Russian Federation are presented in Table 2.

Table 2. Internal expenses for research and development, RUB million

\begin{tabular}{lccccc}
\hline Internal expenses for research and development: & 2008 & 2009 & 2010 & 2011 & 2012 \\
\hline in existing prices & $371,080.3$ & $431,073.2$ & $485,834.3$ & $523,377.2$ & $610,426.7$ \\
in fixed prices of 2000 & 5.57 & 5.49 & 6.07 & 5.87 & 5.89 \\
as a percentage of GDP & 1.12 & 1.04 & 1.25 & 1.16 & 1.12 \\
\hline
\end{tabular}

Thus, internal expenses for research and development as a percentage of GDP constitute $1.04-1.25 \%$. The given below Table 3 shows that absolute volume of internal expenses for research and development in Russia is almost 21 times smaller than in the USA, 7.83 times smaller than in Japan, and 4 times smaller than in Germany.

Table 3. Comparison of internal expenses for research and development in Russia and foreign countries

\begin{tabular}{lcc}
\hline Country & Total, USD million, in 2012 & in \% to GDP \\
\hline Russia & $19,075.83$ & 1.12 \\
Great Britain & $38,707.5$ & 1.77 \\
Germany & $76,796.9$ & 2.64 \\
Israel & $9,921.0$ & 4.86 \\
China & $12,1426.5$ & 1.54 \\
Korea & $45,293.6$ & 3.37 \\
USA & $398,194.0$ & 2.77 \\
France & $42,892.8$ & 2.02 \\
Sweden & $12,781.2$ & 3.75 \\
Japan & $149,212.9$ & 3.42 \\
\hline
\end{tabular}


In our opinion, this data shows that there is no balance of innovative and investment spheres of macro-level yet. Let us view the dynamics of internal expenses for research and development as to sources of financing in the Russian Federation (Table 4).

Table 4. Internal expenses for research and development as to sources of financing, RUB million

\begin{tabular}{lccccc}
\hline All expenses & 2008 & 2009 & 2010 & 2011 & 2012 \\
\hline including as to sources of financing: & $371,080.3$ & $431,073.2$ & $485,834.3$ & $523,377.2$ & $610,426.7$ \\
budget funds & $228,449.2$ & $272,098.8$ & $315,928.7$ & $360,334.2$ & $400,235.7$ \\
own funds of scientific organizations & $30,555.8$ & $35,855.1$ & $35,312.3$ & $47,407.6$ & $73,293.5$ \\
non-budget funds & $6,649.6$ & $6,343.7$ & $7,952.7$ & $10,140.0$ & $8,808.5$ \\
funds of organizations of entrepreneur sector & $77,491.6$ & $89,959.7$ & $94,529.9$ & $85,863.3$ & $99,408.1$ \\
funds of educational establishments of higher & & & & & \\
professional education & 890.0 & 518.1 & 327.2 & 508.2 & $1,568.8$ \\
funds of private non-commercial organizations & 248.3 & 674.9 & 377.3 & 556.5 & 966.5 \\
funds of foreign sources & $26,795.8$ & $25,622.8$ & $31,406.1$ & $18,567.5$ & $26,145.5$ \\
\hline & & & & &
\end{tabular}

The data in the table shows that the state in the main player that understands the importance of innovative sphere. Let us explain it with the help of the data in Table 5.

Table 5. Internal expenses for research and development as to spheres of activities, RUB million

\begin{tabular}{cccccc}
\hline \multirow{2}{*}{ Year } & Total expenses & \multicolumn{4}{c}{ Spheres of activities } \\
\cline { 3 - 6 } & & state & entrepreneurial & $\begin{array}{c}\text { higher professional } \\
\text { education }\end{array}$ & $\begin{array}{c}\text { non-commercial } \\
\text { organizations }\end{array}$ \\
\hline 2008 & $371,080.3$ & $107,984.9$ & $238,386.2$ & $23,471.9$ & $1,237.3$ \\
2009 & $431,073.2$ & $129,871.2$ & $271,206.3$ & $28,868.6$ & $1,127.1$ \\
2010 & $485,834.3$ & $147,023.2$ & $303,051.1$ & $34,642.2$ & $1,117.8$ \\
2011 & $523,377.2$ & $161,988.4$ & $316,701.7$ & $43,714.0$ & 973.1 \\
2012 & $610,426.7$ & $182,135.3$ & $372,088.9$ & $55,134.9$ & $1,067.6$ \\
\hline
\end{tabular}

Table 6. Internal expenses for research and development for top-priority directions of development of science, technologies, and technics as to sources of financing in 2012, RUB million

\begin{tabular}{|c|c|c|c|}
\hline \multirow{2}{*}{$\begin{array}{l}\text { Internal expenses for research and development } \\
\text { for top-priority directions of science, } \\
\text { technologies, and technics }\end{array}$} & \multirow[b]{2}{*}{ Total } & \multicolumn{2}{|c|}{ including the ones financed by funds of } \\
\hline & & $\begin{array}{l}\text { budgets of all } \\
\text { levels }\end{array}$ & $\begin{array}{l}\text { including federal } \\
\text { budget }\end{array}$ \\
\hline & $361,603.7$ & $209,680.1$ & $204,909.3$ \\
\hline \multicolumn{4}{|l|}{ including: } \\
\hline industry of nanosystems & $23,451.7$ & $16,233.5$ & $15,952.3$ \\
\hline informational and telecommunicational systems & $46,609.9$ & $29,260.4$ & $28,242.3$ \\
\hline life sciences & $19,918.8$ & $16,686.4$ & $15,889.6$ \\
\hline rational natural resources use & $29,033.5$ & $15,953.3$ & $15,249.5$ \\
\hline transport and space systems & $148,970.1$ & $84,294.1$ & $83,327.4$ \\
\hline $\begin{array}{c}\text { energy efficiency, energy saving, nuclear } \\
\text { energy }\end{array}$ & $37,318.8$ & $14,929.1$ & $14,720.9$ \\
\hline
\end{tabular}


Table 6 shows internal expenses for research and development as to top-priority directions of development of science, technologies, and technics according to sources of financing in 2012 in the Russian Federation.

The main source of financing of research and development as to top-priority directions are means of federal budget (62.4\%). They constitute more than $80 \%$ for the direction "Live systems". Only the research in the sphere of energy is performed by $52 \%$ by means of non-budget funds. The funds of the budgets of the subjects of the Russian Federation and local budgets provide only $1 \%$ of expenses for R\&D in top-priority directions, including $4 \%$ - in the sphere of rational natural resources use and 3\% - in the sphere of live systems. Thus, budget funds of federal level are the main source for practical realization of the formed priorities.

Thus, there is no balance of investment and innovative activities in the Russian economy yet.

At modern stage of the development of economy, the tasks of planning of well-balanced development of innovative and investment activities of economic systems acquire greater importance. The necessity for provision of well-balanced development of innovative and investment activity is confirmed by the unsatisfying state of activities of many economic systems at macro-, meso-, and micro-levels. It is the balance of these two leading giants - as to the scale of influence on the development of the country's economy - that will allow changing the existing stagnant situation and giving a huge impulse to appearance of a completely new type of functioning of economic systems.

Planning of well-balanced development of economic systems of all levels (macro-, meso-, micro-) supposes the positive changes through coordination and interdependence of elements, factors, and actions, external and internal support and may be represented as a socio-economic process, facilitating the increase of innovational potential of economic system, the basis for which is formation of harmonic innovational and investment sphere.

The determinants which determine this process are the following:

- Existing forms and the character of planning between the subjects of innovative and investment spheres of macro-, meso-, and micro-levels (legal and practical norms of relations, readiness of the state, investors, and innovational business for mutual compromises);

- State of innovative activities of economic systems of macro-, meso-, and micro-levels (volume of economic resources, distributed between scientific, technical, and educational spheres of activities, which business can use for its development), determining the peculiarities of economic interests of economic subjects, specifics and level of development of economic systems, and ratio of technological structures of economic system;

- Existing forms of investment activities for their implementation in innovative development by means of expansion of possibilities in perspective directions of scientific and technical, economic, and social development;

- The system of balance, created by external institutional environment, which forms favorable conditions for development and implementation of new technologies and increase of entrepreneurial activity through the tools of planning. This system of determinants is characterized by clear goals and tasks of development of all economic systems for the specific period of time, which is caused by: usage of all factors (external and internal), guaranteeing favorable conditions for effective functioning and development of economic system; existing unification of innovational processes in national economy; implementation of program-oriented approach to organization of innovative and investment activities; needs of economy in the quick diffusion of innovations within a certain specialization of economic system; necessity for integration of efforts of all subjects of innovative and investment activity; growth of need for shifting the emphasis in the management to the well-balanced development. Thus, the defined determinants of planning of well-balanced development of innovative and investment activity of economic systems determine the peculiarities of formation of harmonized measures which define the algorithm of achievement of set goals, in view of possibilities for the most effective use of investment resources and requirements of scientific and technical progress.

\section{Discussion}

The planning of well-balanced development supposes, primarily, the requirements of structural and qualitative improvement of economy - not just the qualitative one. Among the factors which cause the aggravation of the problem of the balance of the economy, are the accumulated disproportion of intersectoral and intrasectoral nature; aggravation of the problems of economic systems during the planning of well-balanced development of innovative and investment activity, which consists in the necessity for quicker reaction to various shifts, caused by science and technical revolution, change of situation in the global markets, increase of selectiveness of demand for consumer goods, etc. The importance of acquiring the methods of preserving the balance of innovative and investment activities under rapidly changing conditions of economy at macro-, meso-, and micro-levels is especially clear (Serebryakova, Sibirskaya, Stroeva, \& Lyapina, 2014). 
Planning of well-balanced development of innovative and investment activities will allow overcoming (in a simpler way) the existing problem factors, in particular: instability; lack and limitation of means and resources; constant growth of costs; competitiveness; ecological, social, and consumer problems; low level of quality.

Without analyzing and taking into account these problem factors during planning the well-balanced development of innovative and investment activity, there will be negative results, i.e., reduction of income of all members; increase of approximate cost of the project and of its terms; appearance of ков исполнения; fine sanctions for non-fulfillment of obligations; significant lag as to issue of innovational production to the consumer market and, consequently, the production being not innovational; inefficiency of decisions; lot percentage of efficiency of investment activity and increase of terms of projects' pay-off.

Thus, development of modern economy should be viewed as a constant process of creation of conditions for balance of all its components. Therefore, there is a necessity for systematization of measures as to change of dynamics through balance, which is caused not only by certain processes but due to the necessity for perfection this requires deep changes which suppose the recovery of balance on a new, more progressive basis. The task of planning of the balance of innovative and investment activities entered upon the order of the day die to increased lack of resources (innovations and investments) and it stimulates the development of practical recommendations as to improving the mechanism of accommodation of interests of investors and economic systems, which perform the innovative activities, and as to formation of the balance of investments for the purpose of increase of efficiency of innovative activities. For the state and development of innovations and investments in Russia is the result of imbalance, and not an independent economic phenomenon. The realization of this fact is very important for choosing paths, methods, and conditions, for planning of the well-balanced development of innovational and investment spheres (Sibirskaya, Stroeva, Gubareva, \& Mikheykina, 2014).

Among many variants of solutions to general problems, a special attention should be paid to recommendations as to formation of the balance of investments for the purpose of increase of efficiency of innovative activities.

\section{Conclusions}

Recommendations for the formation of the balance of investments for the purpose of increase of efficiency of innovative activities delimit the processes into components: analytical, synthetic, and practical.

Analytical processes of the balance are the complex of directions of activities aimed at the selection of possible variants of investing of innovative activities:

- State support for innovational projects which are implemented by economic systems (macro-, meso-, and micro-levels);

- Targeted investments by means of budgets of all levels through the system of crediting;

- State control for spending budget funds allocated for creation of innovational production;

- Use of various forms of innovative activities (according to the Russian classifier of type of economic activity);

- Creation of technological platform for informational exchange of investors and innovators;

- Provision of co-investing and commercialization of innovational products;

- Formation of investment lift and carry financing.

Synthetic processes of the balance are the list of necessary services, aimed at the determination of rational method of investing innovations:

- Consulting services as to terms of investing of various financial institutions;

- Creation of multi-level system of managerial consulting according to "innovations-investments" elements, types of connections between them, and phases of life cycle in view of peculiarities of making investment decisions of strategic character;

- Preparation of necessary set of documents for the positive contraction of investment bid;

- Presenting clients' interests in financial institutions;

- Consultations as to the time and optimal volumes of attraction of investments.

Practical processes of the balance consist in the implementation of offers aimed at the creation of innovations with active investment activities:

- Active investment policy ensures the innovative activities of economic systems; 
- Creation of corresponding structure of investing innovations, providing the growth of financial pay-off;

- Formation of measures which reduce the risks of investing into innovative activities.

These recommendations can help implementing the well-balanced formation of the whole chain of creation of innovational product and development of effective infrastructure of economic systems investing.

\section{References}

Boudeville, J. R. (1966). Problems of Regional Economic Planning (p. 11). Edinburgh.

Busarina, U. V., Morkovina, S. S., Budkova, S. V., \& Kolesnichenko, E. A. (2014). Mechanisms of Support of Export-oriented Small Enterprises: The Regional Aspect 95. Asian social science, 10(23), 95-102. http://dx.doi.org/10.5539/ass.v10n23p95

Chebotaryov, N. F. (2007). The national innovative system of Russia. Audit and financial analysis, 3, 1-9.

Fayol, A. (1923). The general and industrial department.

Ford. (1924). My life my achievements. Ford [the lane under edition of the process engineer V. A. Zorgenfrey]. L.: Time.

Kaniran, H. M. (2005). Best practicesin ERP software applications. Lincoln.

Keynes, J. M. (1978). The new theory for the changed world. Retrieved from http://www.rus-lib.ru/book/35/eb/ 26/481-518.html

Lundvall, B. A. (1992). National Systems of Innovation. Towards a Theory of Innovation and Interactive Learning. London: Pinter Publishers.

Nadezhda, S., Viktorovna, G. N., \& Vasilievna, S. V. (2014). Sustainable economic development of regions: Monograph (Vol. 5, p. 158). Vienna: "East West" Association for Advanced Studies and Higher Education $\mathrm{GmbH}$.

Planning of needs for materials (MRP). Retrieved from http://12news.ru/doc1646.html

Precisely in time for workers. (2008). Institute of complex strategic researches.

Serebryakova, N., Sibirskaya, E., Stroeva, O., \& Lyapina, I. (2014). The Contents and Structure of Innovative Activity in the Russian Economy. Asian social science, 10(23), 51-59. http://dx.doi.org/10.5539/ass. v10n23p51

Serebryakova, N., Sibirskaya, E., Stroeva, O., \& Petruchina, E. (2014). The Need of the Uniform Information Platform "Innovations of Russia" Formation. Asian social science, 10(23), 78-85. http://dx.doi.org/10. 5539/ass.v10n23p78

Sibirskaya, E. V., Stroeva, O. A., Gubareva, L. I., \& Mikheykina, L. A. (2014). The monitoring of the subject and object of the economic activity population in the innovative sector. Life Sci J., 11(8s), 292-296.

Sibirskaya, E. V., Stroeva, O. A., Khokhlova, O. A., \& Oveshnikova, L. V. (2014). An analysis of investment-innovation activity in Russia. Life Sci J., 11(7s), 155-158.

Small story about Henry Ganta. Retrieved from http://www.mental-skills.ru/synopses/524.html

Taylor, F. U. (1991). Principles of scientific management [An electronic resource]: monograph. Retrieved from http://www.improvement.ru/bibliot/taylor/index.shtm

\section{Copyrights}

Copyright for this article is retained by the author(s), with first publication rights granted to the journal.

This is an open-access article distributed under the terms and conditions of the Creative Commons Attribution license (http://creativecommons.org/licenses/by/3.0/). 